\title{
Construction and Practice of Collaborative Education Platform for Civil Engineering Professionals in Local Universities
}

\author{
Zai-bo LI, Tu-sheng HE and Yong-ping ZHANG \\ Shaoguan University, Shaoguan, Guangdong Province, 512005, China
}

Keywords: Local universities, Civil engineering specialty, Collaborative education

\begin{abstract}
The basic current situation and existing problems of the practical teaching of civil engineering major in local universities were analyzed in this paper. At the same time, the Shaoguan University's recent reform experience of the civil engineering specialty in practical teaching was introduced, and the new mode of collaborative education platform was discussed, which is based on college-enterprise cooperation for the purpose of serving the local economic construction.
\end{abstract}

\section{Introduction}

The reform of higher education in China has made remarkable achievements and the teaching reform has taken a crucial step, but the development of the reform is not balanced in general, and the intensity, speed and depth of educational reform still need to be further improved. For example, in the practical teaching of civil engineering specialty in local universities, outdated concept still exists, and great importance have been attached to classroom teaching, while social practice has been ignored. Meanwhile, some universities still follow the 3-section system-cognition, production and graduation, and there is a certain gap in the integration of practical teaching activities and classroom teaching. For the civil engineering specialty, practical teaching is an important teaching link, which plays an irreplaceable role in cultivating high-quality talents with innovative spirit and practical ability. Based on the fact that Shaoguan University has set up the civil engineering specialty, this paper introduces the school's recent reform experience of practical teaching in this major, and discusses the new mode of collaborative education platform, which is based on college-enterprise cooperation for the purpose of serving the local economic construction.

\section{The Current Situation}

Civil engineering is a traditional applied professional, along with the national infrastructure, real estate and commercial real estate construction scale expands unceasingly, how to provide more and more for the society has the basic theory of solid and strong basic skills of professional applied talents, how to in line with the practical orientation of undergraduate talent education, strengthen the cultivation of students' practical ability, make the students use of successful employment at the same time also can effectively meet the needs of the construction of talent in the field of civil engineering applied undergraduate education is the goal. As a major of application and practicability, practical teaching plays an important role in the teaching system of civil engineering and the cultivation of students' professional ability.

From the survey of the employment direction of civil engineering graduates in Chinese local universities, it can be seen that there are about 70 percent graduates work in construction, about 7 percent in the administrative work of civil engineering, about 15 percent in the design work, about 3 percent in the work of construction and audit, and about 5 percent in other industries. From the data, it also can be seen that most of the graduates are engaged in the technical position in the fore-front production. From the recent working positions of the civil engineering graduates, it is obvious that the graduates who are engaged in the design units become fewer and fewer, while the graduates who are engaged in the construction enterprises increased year by year. This shows that most of the civil engineering professionals cultivated by local universities work in the fore-front production and 
management. In addition, the employing units usually require that the new employees should be equipped with competent practical working experience and can be competent for work soon, but for the new graduates with deficient practical experience it's hard to be hired by the employing units.

Therefore, according to the characteristics of civil engineering, it's necessary to strengthen the practical teaching reforms of civil engineering specialty in local universities and make full use of the strength of social running schools. Besides, setting up a collaborative education platform, which is suitable for applied civil engineering in undergraduate education, and strengthening the cultivation of practical ability will greatly improve the students' ability of application and innovation, thus the social service value of undergraduate education in civil engineering will be realized.

\section{Problem Analysis}

With the change of external environment, such as the employment market and talent demand, and with the shortage of certain resources such as, teaching sites and teachers, which are caused by the enrollment expansion of the local undergraduate universities. Nowadays, there are some problems on the practical teaching in Shaoguan University's civil engineering specialty, and some of the problems are even acute. The main manifestations are as the following: compared with other majors the wide-ranging civil engineering specialty involves engineering design, construction, management, monitoring and other industries, so in the teaching process of civil engineering specialty more practical links is the noticeable feature of this major. Therefore, it is necessary to have a great investment in teaching resources to ensure the smooth development of practical teaching of civil engineering.

Shaoguan University is an application-oriented university in the northern part of Guangdong province, so the talent training goal of the university's civil engineering is to cultivate the licensed engineers who work in the first production line, such as constructors, survey engineers, structural engineers, geotechnical engineers, cost engineer, supervising engineers, and security engineer Because of that, the investment of teaching resources in this aspect between Shaoguan University and the key universities in China should be treated differently, and furthermore, it would make sure that the investment should be pertinent. In this way, the quality and ability of the civil engineering talents can meet the requirement of the local economic development. From the above reasons and the point of improving the benefits of running school, based on the characteristics of talent cultivation in the civil engineering, it is urgent to make full use of social education resources to set up a collaborative education platform, which is suitable for the applied undergraduate education in the civil engineering specialty.

\section{The Contents and Measures of Reform}

\section{Construct the Practical Teaching System in the Mode of College-enterprise Cooperation}

For this goal, it's necessary to optimize the practical teaching content of civil engineering and establish the progressive practical teaching system in engineering, that is: teaching-internship-ability. Meanwhile, to build more practical teaching subjects and improve the students' practical ability in engineering, that is to say the ability of analyzing and solving the practical problems with various in engineering. The practical teaching links with high requirements and long time, such as cognition practice, production practice and graduation practice, should be arranged in the work units of civil engineering construction in the form of groups. In practice, the intern students can involve in the work of construction, management, and design, etc. The interns are required to use virous professional skills and knowledge and solve the problems in construction technique, production organization, and engineering supervision with management of construction technology production organization. 


\section{Strengthen the Practical Link and Build a Stable Campus and Off-campus Practice Bases}

In setting up the collaborative education platform, the requirements of specialty evaluation on bachelor's degree is the guideline and the engineering accreditation is the direction. Based on them, the reforms of specialty and curriculum systems, especially the practical links, should be accelerated. Be active to connect with government departments and off-campus enterprises in order that we can confirm the training target and orientation of civil engineering together. By setting up a variety of modular curriculum group, the curriculum provision and teaching content can fit the market requirements more accurately. There are more measures to create conditions for cultivating the students' practical skills and ability: optimizing the environment of the practical teaching bases, building a stable campus and off-campus practice bases, strengthening the construction of labs of civil engineering, and setting up the sites of practical operation labs of civil engineering, such as laboratories, material labs, structural labs, computer operating labs, professional cartographic chamber, etc.

\section{Establish a Diversified Professional Double-quality Teacher Team}

The experts with superior achievements and rich experience in construction and management, and the young and middle-aged academic leaders should be brought in as cadre teachers on campus practical teaching. At the same time, based on the teaching needs the technicians from enterprises and institutions with strong responsibility in work, love for educational cause and consummate techniques should be chosen and hired as the long-term external faculty team. The organic integration of the cadre teachers and eternal faculty team lay a solid foundation for establishing a high-caliber professional double-quality teacher team. Meanwhile, the professional teachers make use of vacation and work in the enterprises' first production line to practice on planned arrangement, which can improve the teachers' professional skills and horizons. Based on the above situation, in order to keep the close interrelation between curriculum content and production practice, 2-4 enterprise engineering technicians and experts will be hired to teach in college.

\section{Imitate the Enterprise-oriented Teaching Sites}

Make full use of the teaching condition-the civil engineering building in our school to simulate enterprise-oriented teaching sites, which is featured in environment. In this area the students are regulated strictly based on the enterprise-style, while they are cultivated with the professional quality and skills in college.

\section{Improve Social Services Level}

Served as a social service site, the civil engineering building in our school can bring the businesses of engineering design and engineering cost consultation, which are undertook by individual teachers or by colleges, into college to get unified management. It can standardize the social service management, improve the social service level, expand the social service specifications, improve the social service income and enhance the social service ability of teachers and students. In this way, the ultimate goal of improving the talents' cultivation level can be reached, and thus, during the academic years students can come into contact with the real engineering projects.

\section{Summary}

The establishment of the collaborative education platform in civil engineering involves different departments and all staff's participation, and the platform combines colleges, enterprises, government engineering design, so it is more suitable for the civil engineering specialty, which is featured in highly professional standards and government planning.

The collaborative education platform of civil engineering established by our school can share resources, and bring a win-win situation for talents cultivation in universities and social economic development by the operation of college-enterprise cooperation and marketization. The establishment 
of the platform in civil engineering also make the two parties (i.e. colleges and society) get further unification in staff, asset, and practical teaching and get further optimizing in the resources of school running.

The implementation of this project involves various fields of civil engineering, such as, design, construction, engineering projects management, which can stimulate students' learning interest and innovative ability.

The mode of school-enterprise cooperation enables students to integrate into a group to learn, practice, and cooperate, which helps the students develop the self-management habit that is suitable for collective production and enhance their sense of responsibility.

\section{Acknowledgement}

This research was financially supported by the Foundation of Guangdong Educational Committee (2016[233]) and the Foundation of Shaoguan University (SYJY20171811 \& SYJY 20151653).

\section{References}

[1] Chen Guixiang. On the Formation of Innovative and Entrepreneurial Talents Cultivation Mechanism with Linkages among University, Government and Enterprise, University Education Science, 2015, (01): 42-47.

[2] Fang Sanhu, Zhang Yongliang, Xie Qingmei. Reform and Practice of Training Applied Talents for Agricultural University Based on Cooperative Education, Research and Exploration in Laboratory, 2016, (04): 219-222.

[3] Wu Aihua, LiuXiaoyu. Promoting the Cooperation between Universities and CAS Institutions for Talent Cultivating, Research in Higher Education of Engineering, 2015, (02): 6-9.

[4] Wu Qi, Li Ruijuan, Jin Wen. Discussion on School-Enterprise Cooperative Education of Local Application-oriented Undergraduate Universities, Research and Exploration in Laboratory, 2017, (09): 247-250.

[5] Guo Wenli. Transformation and Construction Training Mode Reform of Application-oriented Engineering Talents in Local Universities with Industry Background, Research in Higher Education of Engineering, 2012, (04): 25-33. 